GLOBAL JOURNAL OF EDUCATIONAL RESEARCH VOL 17, 2018: 127-137

COPYRIGHT@ BACHUDO SCIENCE CO. LTD PRINTED IN NIGERIA. ISSN 1596-6224 www.globaljournalseries.com; Info@globaljournalseries.com

\title{
MANAGEMENT OF SCHOOL CLIMATE AND TEACHERS' JOB PERFORMANCE IN SECONDARY SCHOOLS IN CALABAR EDUCATION ZONE, CROSS RIVER STATE
}

\section{EMU, WINIFRED HARRY AND NWANNUNU, BLESSING IHEOMA}

(Received 21, September 2018; Revision Accepted 5, December 2018)

\begin{abstract}
This study examined the influence of management of school climate and teacher's job performance in secondary schools in Calabar education zone, Cross River State, with variables as safety of school environment and principal's leadership style as they influence teachers' job performance. The study adopted the survey research design. Two research questions and research hypotheses were formulated and tested using One-way Analysis of Variance (ANOVA). The population of the study was 2,313 teachers and 98,367 students spread across the 72 public secondary schools in Calabar education zone. The Yamene's formula was used to determine the sample size which gave a total number of 400 for both teachers and students. Questionnaire was structured on a 4 point-likert scale for the collection of data. The results of the study showed that safety of school environment and principal's leadership styles significantly influence teachers' job performance. It was therefore recommended that school administrators must ensure that both class and staff rooms are well equipped and properly ventilated while the topography of the school building and environment must convey the spirit of learning and as well, principals must be liberal in their dealings with teachers and students so as to enhance teachers' job performance.
\end{abstract}

KEY WORDS: Safety of School Environment; Principal's Leadership Style; Teachers Job Performance.

\section{INTRODUCTION}

The quality of a nation's educational sector depends considerably on teachers as well as the collective interactions of the internal and external forces that intervene in the fulfillment of the purpose for setting up schools. The effectiveness and stability of the schools is mostly based on their school climate and the satisfaction of teachers (Wentzel and Watkins, 2002). According to Homana, Barber and Torney-

Purta (2006), school climate refers to the

Emu, Winifred Harry, Department of Educational Administration and Planning University of Calabar, Calabar. Nigeria.

Nwannunu, Blessing Iheoma, Department of Educational Administration and Planning University of Calabar, Calabar. Nigeria. 
quality and character of school life or the overall characteristics and atmosphere in the school. It is based on patterns and the safety of the school environment, experiences and principal's leadership practices (Adeyemi, 2004).

Teachers, as important members of the school play pivotal roles in educating the students. However, where the school climate becomes unfavourable, that is, where the school and physical environments are not

safe, the

principal leadership is autocratic; this can affect teachers' job performance and student's learning outcome. Therefore, the need for effective management of school climate becomes imperative (Ghazi, 2003).

Wentzel and Watkins

established that management of the school climate entails the application of techniques and expertise of efficient organization, planning, direction, and controls to the operations of the school, its students, teachers and immediate environment. It entails the effective administration of the school in order to achieve academic excellence and to erode decadence. This is because the efficiency of a school system depends to a large extent on how human and material resources are motivated and effectively utilized within a conducive environment to enhance teachers' job performance. However, there is no doubt that, students' performance in examination is a criterion to gauge teachers' job performance.

The spate of derecognizing secondary schools in Calabar Education Zone by the West African Examinations Council (WAEC), and the National Examinations Council (NECO) and abysmal poor academic performance is alarming that one begins to wonder if teachers are performing their duties or jobs well. Evidence from the report of Ejiogu (2015) shows that students' performance in English language and Mathematics in NECO was reduced by 45 percent between 2012 and 2014 while students' performance in English Language in
WAEC reduced by 29.5 percent between 2013 and 2014.

On the account of the forgone argument or scenario, it is obvious that the way school climate is managed has a significant role on teacher's job performance which in turn may have a negative or positive impact on students' academic performance. It is consequent upon this background that this study seek to investigate the relationship between management of school climate and teachers job performance in secondary schools in Calabar education zone.

\section{Statement of the problem}

The deteriorating state of students' academic performances in the West African Examination Council (WAEC), National Examination Council (NECO) examinations and other internal and external examinations between 2010 to 2014 are alarming. These unwholesome results, have questioned teachers' capacity to perform effectively. Teachers' job performance in secondary schools has been put under observations while, it has been established that teachers' low performance were premised on their lack of teaching skills and students' reading habit; whereas, the management of school climate which is fundamental to teachers' effectiveness was left in abeyance.

Evidentially, most public secondary schools in Nigeria are not safe for teaching and learning. School environments are without adequate security while, visitors and students move in and out the school premises at their own leisure. Other obvious issues include hostility among staff, dilapidated building and infrastructure and unfriendly school environment.

The attitude of some principals are equally devastating as they issue orders arbitrarily, use abusive languages on teachers and usually take side where there is a problem among staff or students. These exhibitions no doubt have untold effects on teachers job performance which mostly demoralizes them. Another important issue is on principal's leadership style that is mostly one-sided and 
not neutral in the disposition of academic matters. It is against this backdrops the study evaluates the management of school climate and teachers' job performance in secondary schools in Calabar Education Zone of Cross River State.

\section{Purpose of the study}

The aim of the study is to examine the influence of management of school climate on teacher's job performance within public secondary schools in Calabar Education Zone in Cross River State. Specifically, the purpose of this study is to find out the extent to which:

1. Safety of school environment influences teachers' job performance.

2. Principal's leadership style influences teachers' job performance.

\section{Research questions}

The following research questions were stated to guide the study

1. To what extent does safety of school environment influence teachers' job performance?

2. To what extent does principal's leadership style influence teachers' job performance?

\section{Statement of hypotheses}

The following hypotheses were stated to direct this study

1. Safety of school environment does not significantly influence teachers' job performance.

2. Principal's leadership style does not significantly influence teachers' job performance.

\section{LITERATURE REVIEW}

\section{Safety of school environment and teachers' job performance}

Safe environment is an essential factor for viable adapting, so much that the America's real instruction change activity, No Child Left Behind, requires educational systems to have programs set up to diminish levels of savagery as a feature of its bigger arrangement to enhance scholastic execution (Karpicke and Murphy, 1996). Learners that are afraid of violence tend to skip school. A study of sophomores in most high schools indicates that learners who attended schools with significant to abnormal levels of brutality were less inclined to graduate or acquire a higher degree.

Risky situations can likewise negatively affect learning capacity. Learners in unsafe school situations will probably be harmed, be involved in gang battles as well as encounter enthusiastic anxiety. Furthermore, teenagers who are included in tormenting (a typical type of brutality in schools) either as a culprit or casualty, will probably experience the ill effects of depressive indications, for example, hopelessness and trouble making companions, are more prone to confront psychosocial modification issues. Inclusion in tormenting as a harasser or casualty is likewise connected with poorer wellbeing results; while being a bully is often connected with alcohol consumption (Blanche and Durrheim, 1999).

School safety is critically linked to School climate (NASBE, 1994). A safe school environment enhances adequate background for teacher's job performance and advancement of positive attitudes. Teachers connected with the school (that is, exhibit that feelings of being safe, and as well want to be managed well by the school administrators, and hence happy to do their job, and develop that citizenship behaviour) encounter less misery and take part in their work with utmost proficiency (Blum, 2002).

According to Megan (2002), most schools that are within high-risk urban environments but with positive support systems together with a school environment safety consciousness promote teachers' job performance and effectively shape the level of scholarly achievement experienced by urban learners. Moreover, experts have found that positive school atmospheres are essential components of a strong learning environment and stimulate teachers' effectiveness especially to punctual learners. A positive school climate therefore encourages properly 
motivated teachers. This was further corroborated by Johnson, Livingston, Schwartz and Slate (2000), who added that safe groups where learners feel protected and secured builds educator assurance, work fulfillment, and maintenance. The association of different qualities of school and classroom atmosphere to the school's wellbeing can empower all individuals from the school to learn as well as to perform at ideal exceptional levels (Pashiardis, 2000). However, a negative school atmosphere such as where school violence is rife interferes with learning and development.

Different reviews show that learners and teachers in schools with a serene and hostilefree learning environment have greater accomplishment and improved wellbeing. The aura of a school in line with teachers' achievements has been known to result in examination excellence (Neuman and Simmons, 2000).When teachers feel secure, they are more agreeable in their schools, are more eager to educate and succeed, and have better chances to develop scholastically, inwardly, and socially. Therefore, a protected school environment is essential for teachers' job performance.

Building safe, violence-free schools contributes to the overall goals of teachers. Research shows that school brutality is for the most part a manifestation of bigger group issues, for example, substance abuse, misery and other psychological wellness issues, and poor scholastic accomplishment. The activities and services that promote safe schools are the same ones that can foster teachers' development. To maximize effectiveness, activities that address safety of schools and communities should be integrated with programmes that address the other four elements. Schools are an opportune setting for identifying and observing students who are at risk of becoming disruptive or violent, or reintegrating those who have committed offenses. These students not only have a harder time achieving academic success, but may also negatively impact their fellow students' learning and feelings of safety, and may occupy a disproportionate amount of teacher and administrator time. In addition to identifying threats to school safety, school administrator can promote student and staff behaviors that create safer environments, such as rewarding those who display acts of kindness and good citizenship (Bolman and Deal, 2002).

\section{Principal's leadership style and teachers' job performance.}

School managements confront an assortment of issues consistently. Each school head has an individual instructive administration theory. This theory covers a large number of issues which school heads will experience every day. The strength of any school lies in its leadership. An efficient school leader handles the responsibility with care without placing priority on any extrinsic reward, but needs to develop or sharpen his or her skills towards taking or making decisions that will better off the life of the school as well as the students' wellbeing.

Leaders are perceived to be people who set directions and impacts individuals to take after that course. Researchers have been able to characterize common authority styles and relating them to different parts of hierarchical results (Ekpo, Akpan, Essien and Imo-Obot, 2009). In any case, current researches have concentrated on the perception of a leader as a person who knows what has to be done and then mobilizes both human and material resources to get it accomplished.

Principal-teacher interactions changes among schools and even among instructors in a similar school. Moreover, those interactions influence teachers' job performance (Walsh, 2005). This is due to the fact that teachers who consider principals to be facilitators, supporters and reinforcersof the stated school's mission instead of as guiders, chiefs, and pioneers of their individual motivation are significantly more inclined to feel more responsible for students' learning (McEwan, 2003).

Teachers job performance is intricately linked with the domain of responsibility (Eicher, 
Hawkridge, MacAnany, Mariet and Orivel, 1992). When a school with poor overall performance puts in place machineries for reversing the ugly trend, teachers usually take responsibility for what transpires in their classrooms. When the atmosphere in a school getstensed and teachers see principals as suspicious and negative, an urgent review of the principal's leadership style is required to provide a conducive atmosphere for teaching and learning.

In this regard, principals can enhance the work ethics of teachers by providing physical space and recreational activities. This helps to promote the ideals of collegiality and comradeship (Firestone and Pennel, 1993).

Achieving the goal of collective effort in a school setting is not that simple. It carries with it a measure of trouble and even of uneasiness once in a while. Collaborative efforts work in the realm of thoughts, looking at the prevailing practices and ways of enhancing educational performance of learners. This is accepted to be one of the key difficulties for shared working and expert improvement (Hargreaves, 1992). Leadership enhances effective school administration and encourages good teachers' student association which improves educational performance of learners. It has been observed that positive school leadership has a significant effect in building up teachers' enthusiasm for school activities, image and occupational fulfillment (Camman, Fischman, Jenkins, and Wesh 1993).

To be effective as a transformational leader, principals must be flexible enough to embrace leadership methodologies and styles reasonable for progressive school association (NEAGE, 2009).In this vein, Kearneya as cited in Popoola (1994)opines that participative leadership approach which encourages staff involvement in decision making enhances their job accomplishment and make them feel valued by their institutions. Smith (1998) emphasizes that when employees' duties are properly designated and there is a cordial association between the administrators and workers, there is bound to be an improvement on workers' performance and learners' educational attainment. Essentially, while the despotic leadership style is for the most part narcissistic and only encourages minimal investment insubordinates, the just style is fairly individual-centered and relies on the participatory commitment of the subordinates (Mgbodile, 2004).

In the study of Nicholson and Patricia (2002) on transactional and transformational leadership and their effect on occupation fulfillment; found that value-based initiative was not decidedly identified with employment fulfillment but rather that transformational leadership was. They concluded that adequate application of this leadership style could lead to improve teachers' management relationship. Adequate application of appropriate leadership style could motivate and enhance the behaviour of employees (Siskin, 1994). It is the sign of the prevailing conduct of administrators (Okurumeh, 2001). It is likewise a procedure through which people or gathering impact others in the fulfillment of their objectives (Adeyemi, 2006). Accordingly, Ibukun (1997) contended that basic duties of principals is to ensure enhance and favourable working environment for teachers and learners alike in order to enhance their performance. In favour of this contention ljaiya (2000) stated that teachers in secondary schools in the country prefer to be involved in decision making in order to improve their employment relationship with the school management. Researchers have distinguished few leadership practices utilized in most institutions (Nias, 1994).

\section{METHODOLOGY}

The study employed the survey research design. The survey research design was used because it encourages the administration of questionnaire to respondents in order to obtain data on the management of school climate and teachers' job performance.The research area covered under investigation was Calabar Education Zone spanning across six education district which include: Akamkpa, Akpabuyo/ Bakassi, 
Biase, Calabar Municipality, Calabar South and Odupkani Education Districts, CEZ, Calabar Education Zone.The target population of the study comprises 2,313 teachers and 98,367 students of 72 public senior secondary school within Calabar Education Zone (CRSSEB, 2015).

The stratified random sampling technique was employed in order to determine the population quota of teachers and students in each district and the judgmental sampling was also used for choosing the actual respondents in each educational zone. Calabar educational zone statutorily comprises six strata. In view of the researcher's inability to reach-out to the entire population of 100680 teachers and students of public secondary School a sample of 400 teachers and students across the six educational districts in Calabar educational zone was arrived at using Yamane (1965) statistical formula on the population size of 100680.

\section{RESULTS AND DISCUSSION}

The study was on the management of school climate and teachers' job performance in secondary schools in Calabar Education Zonee. The sub variable identified were safety of school environment, principal's leadership style, and teachers' job performance. Data for the study were collected using research questionnaire which were distributed to all the sampled school across Calabar Education Zone. The result of general description of the research variable was presented in Tables 1 below.

TABLE 1: Summary of descriptive statistic with management of school climate and teachers job performance in secondary school in Calabar Educational Zone $(n=400)$

\begin{tabular}{llll}
\hline S/N & VARIABLE & - & SD \\
& & $\mathbf{X}$ & \\
\hline 1 & Safety of school environment & 15.87 & 2.66 \\
2 & Principal's leadership style & 15.62 & 2.75 \\
3 & Teachers job performance & 18.12 & 3.05 \\
\hline
\end{tabular}

Source: Fieldwork, 2016

Presentation of results

Results of data collected were presented hypothesis by hypothesis with the aid of Oneway analysis of variance as shown below:

\section{Hypothesis one}

Safety of school environment does not significantly influence teachers' job performance

To test hypothesis one, data on safety of school environment and teachers' job performance from the six education districts in Calabar Education Zone were collected through the research questionnaire. Result of the analysis is presented in Table 2. 
TABLE 2: One-way Analysis of Variance of the influence of safety of school environment on teachers' job performance

\begin{tabular}{|c|c|c|c|c|c|c|}
\hline Group & & $\mathrm{N}$ & $\bar{x}$ & & SD & \\
\hline High influence & & 184 & 16.06 & & 3.12 & \\
\hline Moderate influence & & 124 & 16.96 & & 2.05 & \\
\hline Low influence & & 92 & 17.28 & & 2.32 & \\
\hline Total & & 400 & 16.85 & & 2.52 & \\
\hline Source of variance & Sum of squares & Df & Mean square & F-value & & Sig \\
\hline Between Group & 58.75 & 2 & 58.75 & 16.31 & & 001 \\
\hline With Groups & 1432.44 & 397 & 3.60 & & & \\
\hline Total & 1491.19 & 399 & & & & \\
\hline
\end{tabular}

$P<0.05$ (Critical $F=3.84$ )

Source: Field work, 2016

TABLE 3: Post-hoc comparison with Fisher's Least Significance Difference (LSD) with the influence of safety of school environment on teachers' job performance

\begin{tabular}{|c|c|c|c|c|}
\hline $\begin{array}{l}\text { Influence } \\
\text { environment }\end{array}$ & school N & High influence & $\begin{array}{l}\text { Moderate } \\
\text { influence }\end{array}$ & Low influence \\
\hline High influence & 184 & 16.06 & -.67 & .00 \\
\hline Moderate influence & 124 & -3.12 & 16.96 & -.67 \\
\hline Low influence & 92 & $\begin{array}{l}0.00 \\
\text { MSW } 3.60\end{array}$ & -2.28 & 17.28 \\
\hline
\end{tabular}

Source: SPSS output, 2016

$P<0.05$, Critical $t=3.84$, df 397

The result of the analysis shows the inferential and descriptive statistics for the influence of school environment on teachers' job performance in Calabar Educational Zone. The result reveals that safety of school environment has high influence on job performance of 184 teachers' with mean and standard deviation of 16.06 and 3.12 respectively. Teachers that were moderately influenced by their school environment were 124 with mean and standard deviation of 16.96 and 2.05 while those with low influence were 92 with mean value of 17.28 and standard deviation of 2.32 .

The result of One-way Analysis of Variance shows that between groups sum of square was 58.75 with a mean square of 58.75 , while within group sum of square value was 1432 with mean square within of 3.60. The degrees of freedom were 2 and 387 . The calculated $F$ value of 16.31 was greater than the critical value of 3.84. Based on this result, the null hypothesis was rejected in favour of the alternative. This implies that safety of school environment significantly influence teachers' job performance in Calabar Educational Zone. To determine which of the groups differ significantly, a pair-wise (Post-hoc) multiplecomparison was done with Fisher's Least Significant Difference (LSD) as presented in Table 3.

The post-hoc analysis in Table 3 shows that the mean score for high influence and moderate influence of safety of school environment were statistically significant as $(t=-3.12 ; p=003$ and $X=67)$. For teachers 
with high and low influence of safety of school environment, the Fisher's Least Significance shows that there was no significance between the two group means as $(t=0.00 ; P .982$, and $X=000$ ), while for moderate and low mean difference, there was significant mean difference as $(\mathrm{t}=-2.28 ; \mathrm{P}=025$ and $\mathrm{X}=-67)$.

Hypotheses two
Principal's leadership style does not significantly influence teachers' job performance.

To test hypothesis four, data on principal's leadership style and teachers' job performance from the six education districts in Calabar Education Zone were collected through the research questionnaire. Result of the analysis is presented in Table 4 below:

TABLE 4: Result of One-way Analysis of Variance of the influence of Principal's leadership style on teachers' job performance

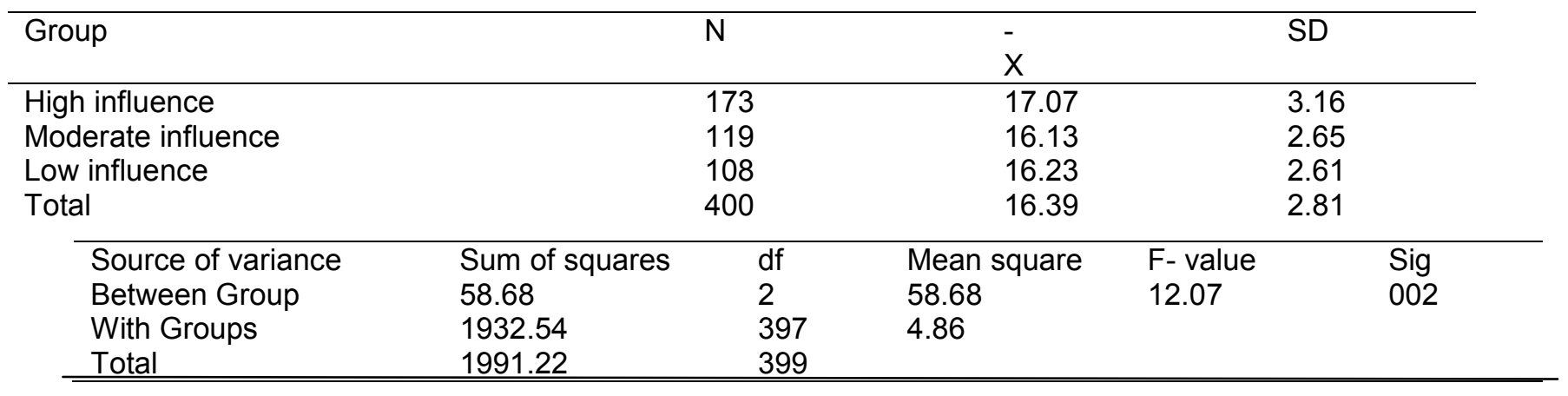

$P<0.05$ (Critical $F=3.84)$

TABLE 5: Post-hoc comparison with Fisher's Least Significance Difference (LSD) of the influence of principal's leadership style on teachers' job performance

\begin{tabular}{|c|c|c|c|c|}
\hline $\begin{array}{l}\text { Influence of } \\
\text { environment }\end{array}$ & school N & High influence & $\begin{array}{l}\text { Moderate } \\
\text { influence }\end{array}$ & Low influence \\
\hline High influence & 173 & 17.07 & $.72^{*}$ & $1.07^{*}$ \\
\hline Moderate influence & 119 & .21 & 16.13 & .31 \\
\hline Low influence & 108 & $\begin{array}{l}3.03 \\
\text { MSW } 4.86\end{array}$ & .84 & 16.23 \\
\hline
\end{tabular}

Source: SPSS output, 2016

$P<0.05$, Critical $t=3.84$, df 397

$a=$ Group mean are placed along the diagonal

$\mathrm{b}=$ Difference between group means are placed above diagonal

$c=$ Fisher LSD are place below the diagonal

The result of One-way Analysis of Variance (ANOVA) in Table 4 reveals the influence of principals' leadership style on teachers' job performance in Calabar Educational Zone. The result shows that principals' leadership style had high influence on 173 teachers' job performance with mean value of 17.07 and standard deviation value of 3.16. Teachers that were moderately influenced by principals' leadership style were 119 with mean and standard deviation of 6.13 and 2.65 respectively while those with low influence of 
principals' leadership style were 108 with mean value of 16.23 and standard deviation of $2.61 \mathrm{j}$.

The One-way Analysis of Variance shows between group sum of square value of 58.68 with a between mean square of 58.68 , while within group sum of square value was 1932.54 with mean square of 4.86. The degrees of freedom were 2 and 387 . The calculated $F$ value of 12.07 was greater than the critical value of 3.84 . Based on this result, the null hypothesis was rejected in favour of the alternative. This implies that principals' leadership style significantly influence teachers' job performance. Post-hoc comparison with Fisher's Least Significance Difference (LSD) was carryout to determine the mean difference among groups as shown in Table 5.

The result of mean comparison with Fisher Least Significance Difference in Table 5 shows that the mean score for high influence and moderate influence of principals' leadership style was statistically significant as $(t=.21 ; p=024 \ldots$ and $X=.72)$. For teachers with high and low influence of principals' leadership style, the Fisher's Least Significance indicates that there was no significant difference between the two group means as $(t=3.03 ; P=000$, and $X=1.07)$, while for moderate and low, there was no significant mean difference as $(t=84 ; P=.334$ and $X=31$ ) in terms of the influence of principal's leadership style.

\section{Discussion of findings}

Safety of school environment and teachers' job performance

The research question was stated as to what extent does safety of school environment influence teachers' job performance? From the analysis of hypotheses one, it was revealed that safety of school environment significantly influence teachers' job performance. It is clearly observed that this result is in consonant with the findings of Megan (2002) who specifies that school that is within a high-risk urban environments but possess a positive, supportive atmosphere with a safety of school environment consciousness induces teachers' job performance. This result was further corroborated with the work of Freiberg (1998) who affirmed that schools that practices inclusive learning recoded high teacher morale, job satisfaction, and retention.

Principal's leadership style and teachers' job performance

The research question was stated as to what extent does physical school environment influence teachers' job performance? The result from the test of hypothesis three shows that physical school environment significantly influences teachers' job performance. This finding was supported by Farombi (1998) who indicates that school environment may have negative impact on learners' scholarly accomplishment particularly if such environment lacks infrastructure which could aid leaning and enhance teachers performance. Farombi additionally state that school infrastructure is a critical component in enhancing teachers performance and learners academic accomplishment.

\section{Conclusion}

It is clear that management is one of the most important human activities that permeates all organisations including schools. When people work together for attainment of predetermined objectives, there is need for management. Many people consider organizational/ school climate too complex to be controlled. However, seasoned school adminstrators can improve school climate by making necessary changes that will move teachers from anxiety to confidence and from isolation to connection. It is obvious that the way school climate is managed plays a significant role on teachers job performance which in turn may have a negative or negative impact on students' academic performance. The teachers on their parts have complained about principal's leadership style, poor and unsafe environment. In other words, teachers feel that the way the school is managed seems to affect their output in terms of their job performance. 


\section{Recommendations}

Based on the findings of the study, the following recommendations were made:

1. School administrators must endeavor to have qualified security operatives within the school environment while students with ungentlemanly character should be punished accordingly.

2. Principals must be liberal in their dealing with teachers and student so as to enhance teachers' job performance.

\section{REFERENCES}

Adepoju, T. L., 1996. The factors militating against effective planning and implementation of educational policies

in Nigeria. A Paper Presented At The WAEC Monthly Seminar, WAEC National Secretariat Yaba, Lagos.

Adeyemi, J. K., 2004. Resource situation and internal efficiency of technical Colleges in Nigeria. Unpublished Ph.D Thesis, University Of Ibadan.

Blanche, L., and Durrheim K., 1999. Research in practice: Applied methods for the social sciences. Cape Town: University of Cape Town Press.

Blanche, L., and Durrheim K., 1999. Research in practice: Applied methods for the social sciences. Cape Town: University of Cape Town Press.

Blum, C.E., 2002. Analyzing schools as organisations long-term permanent

and short-term change. Social Education Extra Issue, 5,100-114

Bolman, L., and Deal, T., 2002. Leading with soul and spirit.The School Administrator, 59(2), 21-26.

Bucker, F., 1988. Assessing the attitude and perception of organization members. New York: John Wiley.
CRSSB (2013).Information on Cross River

State public schools. Retrieved from www.CRSSB.COM/35742

Ejiogu, A., 2015, The Nigerian teacher more sinned against than sinning. In emergent issues in Nigerian education. International Journal of Arts and Humanities5 (1), 23-32.

Ekpo, K., Akpan, O., Essien, E., and ImoObot, M. M., 2009. Classroom climate and students' academic achievement in social studies in Cross River State, Nigeria. An International Multi413- 428. Disciplinary Journal, Ethiopia, 3 (4),

Elisabeth, W., and Shuard, H., 1988. Primary mathematics today $3 r$ Ed.. Florida: Longman Group Press.

Firestone W. A., Pennel, J. R., 1993. Teacher commitment, working conditions and differential incentive policies. Review of Educational Research, 63 (4), 489525.

Getzel J. W., 2003 Social behaviour and the administrative process. Journal of Review 65(2), 315-373

Homana, G., Barber, C., and Torney-Purta, J., 2006. School citizenship education climate assessment. New York:

National Center for Learning and Citizenship Press.

Johnson, J., Livingston, M., Schwartz, R., and Slate, J., 2000. What makes a good elementary principal? A critical examination. Sheffield: Corwin Press.

Karpicke, H., and Murphy, M., 1996. Productive school culture: Principals working from the inside. NASSP Bulletin, 80 (2), 26-34. 
Peretomode, V. F., 1999. Educational administration: Applied concepts and theoretical perspectives. Lagos: Joja Publishers. Educational Research and

Peterson, K., and Deal, T., 1998. How leaders influence the culture of schools. Educational Leadership Review,

56(1), 28-30.

Popoola, D., 1994. Job satisfaction and employee motivation in institutions of higher education: The University of Lagos experience. Education and Development, 4(1), 417-425.
Smith, P. B., and Peterson, M. F., 1998. Leadership, organizations and culture: An event management model. London: SAGE Publications

Walsh, K., 2005. Supervision for better schools. Englewood-Cliffs: PrenticeHall.

Wentzel, K. and Watkins, D., 2002. Peer relationships and collaborative learning environment of teaching as contexts for academic enablers. School Psychology Review, 31(3), 366-367.

Yamane, T., 1967.Statistic: An introductory analysis. New York: Haper and Raw. 